\title{
PALAVRA DE DEUS, NA NEO-ORTODOXIA, SEGUNDO KARL BARTH
}

\author{
José Elenito Teixeira Morais, Luiz Carlos Ferreira \\ e Renata Ferreira Gomes*
}

\begin{abstract}
RESUMO
ABSTRACT

O liberalismo teológico tentou

The theological liberalism has conciliar o cristianismo com as aspirações humanas. Neste contexto surge a neo-ortodoxia barthiana, na qual Karl Barth busca fazer um estudo da Bíblia através da Bíblia, mas descobre que isso não é possível e, mesmo questionando o método histórico crítico, ele o utiliza e chega a seu conceito de Palavra de Deus.

Palavras-chave: Karl Barth, neo-ortodoxia, liberalismo, Palavra de Deus. tried to reconcile Christianity with human aspirations. In this context the neo-orthodoxy Barthian, in which Karl Barth seeks to do a Bible study through the Bible, but discovers it is not possible and even questioning the historical critical method, he uses it and gets to his concept of God's Word.

Key-words: Karl Barth, neoorthodoxy, liberalism, Word of God.

\section{INTRODUÇÃO}

Este artigo apresenta o contexto em que surgiu a neo-ortodoxia, seu conceito e como, dentro deste período, Karl Barth passou por essa transição de sua teologia, chegando finalmente ao conceito de Palavra de Deus.

Barth (1886-1968) foi um dos grandes nomes da Teologia Cristã Protestante. Educado na Teologia Liberal, tendo como principal orientador Adolf Von Harnack, ele decepcionou-se com esta teologia e inclusive com seu mentor, por apoiarem publicamente a política de guerra do Kaiser Wilhelm II, da Alemanha, em 1914.
\end{abstract}

* Os autores são Bacharéis em Teologia pelo Centro Universitário Metodista Izabela Hendrix, FATE-BH. Belo Horizonte, MG. 
John Landers, em seu livro Teologia Contemporânea (1986, p. 6), diz que mesmo desiludido Barth continuou a pregar e, estudando a Bíblia, encontrou uma nova fonte que revelou a superficialidade da teologia na qual havia sido criado. Nesse período, descobriu os escritos de Sören Kierkegaard, sendo assim influenciado por eles. De uma teologia dialética, Barth parte para uma teologia de analogia da fé. ${ }^{1}$ Tratar da transição da teologia de Barth rumo ao desenvolvimento de seu conceito de Palavra de Deus é o que este artigo propõe. Primeiramente será especificado o contexto em que surgiu a neo-ortodoxia; em seguida, seu conceito em si, e finalmente o conceito de Palavra de Deus em Karl Barth.

\section{CONTEXTO QUE ANTECEDE A NEO-ORTODOXIA}

A Teologia Liberal surgiu em meados do século XIX e tentou conciliar os conceitos da Igreja Protestante com as aspirações humanas positivas, buscando uma adaptação entre religião, pensamento e cultura moderna, que são influências do lluminismo e Racionalismo. Neste período tudo era submetido a uma análise racional, incluindo a Bíblia. Com isso, a fé foi rebaixada pela razão humana, que triunfou sobre ela. Para este movimento teológico, o amor a Deus é realizado basicamente no amor ao próximo, e o Reino de Deus é visto como uma realidade presente encontrada na sociedade transformada sob o aspecto ético. Neste mesmo período é enfatizado o método histórico-crítico de interpretação da Bíblia, que negava a inspiração divina das Escrituras e abalou a confiabilidade desta. O antropocentrismo crescia e a importância das Escrituras era diminuída a meros relatos humanos.

O liberalismo teológico clássico foi uma reação contra o poder da religião institucionalizada, e principalmente contra a aceitação da infalibilidade das Escrituras e inerrância da Palavra de Deus por parte da Igreja. Fundamentado no lluminismo do século XVIII, ele afirmava que o conhecimento tradicional sobre Deus, pensado de forma metafísica, não compactua com o conhecimento científico. Não havendo espaço para categorias como sobrenatural na história, esta seria apenas uma mera relação de causas e efeitos.

Essa compreensão deu início a uma busca da Palavra de Deus dentro das Escrituras, tornando-se mais intensa com a utilização do método

1 Cf. LANDERS, John. Teologia Contemporânea. Rio de Janeiro: JUERP, 1986. p. 6. 
histórico-crítico, que ousou fazer a separação entre as duas coisas. Os críticos então tinham o direito de emitir juízos sobre afirmações bíblicas como sendo ou não verdadeiras. Os primeiros estudiosos que aplicaram este método ao estudo das Escrituras negavam que a Bíblia fosse, de fato, a Palavra de Deus inspirada.

J. G. Machem, em seu livro Cristianismo e liberalismo, traz uma pequena comparação entre o cristianismo e o liberalismo, tratando do assunto com muita propriedade. Diante da tentativa dos liberais de removerem do cristianismo todas as coisas que não podem ser autenticadas pela ciência, tais são suas palavras:

O liberalismo representa a fé na humanidade, ao passo que o cristianismo representa a fé em Deus. O primeiro não é sobrenatural, o último é absolutamente sobrenatural. Um é a religião da moralidade pessoal e social, o outro, contudo, é a religião do socorro divino. Enquanto um tropeça sobre a "rocha de escândalo", o outro defende a singularidade de Jesus Cristo. Um é inimigo da doutrina, ao passo que o outro se gloria nas verdades imutáveis que repousam no próprio caráter e autoridade de Deus. ${ }^{2}$

Os liberais acreditavam que a Igreja Cristã se perdera na interpretação da Bíblia através dos séculos e era necessário expurgar dos relatos bíblicos os mitos, fábulas, lendas e acréscimos, tais como os mitos da criação e do dilúvio, e de personagens imaginados como Adão e Moisés. Para eles, a Bíblia era considerada documento humano, cuja validade principal estava em registrar a experiência de pessoas que testemunham a fé em Deus e os valores; também os conceitos que ela trazia podiam ser vistos como culturalmente condicionados e irrelevantes aos tempos modernos. Esse era o motivo pelo qual achavam que a Bíblia deveria ser reinterpretada à luz dessas convicções.

\section{CONCEITUANDO A NEO-ORTODOXIA}

A palavra neo-ortodoxia é de origem grega. Etimologicamente, seu significado é neos: novo; orthos: verídico e doxa: crença, ou seja, uma nova e

2 Cf. MACHEM, J. Gresham. Cristianismo e Liberalismo. São Paulo: Puritanos, 2001. p. 182. 
verdadeira crença. Apesar de haver outros nomes ligados à neo-ortodoxia, como Emil Brunner e Richard Niebhur, esta teologia ficou também conhecida como barthianismo, devido à grande influência do teólogo Karl Barth. $\mathrm{O}$ contexto histórico em que surgiu explica o motivo da teologia de Barth vir a ser chamada de neo-ortodoxia.

A neo-ortodoxia surgiu como uma reação ao liberalismo teológico. Em 1919, Karl Barth publicou o comentário sobre a carta aos Romanos, que chamou a atenção dos círculos acadêmicos. Neste comentário ele expôs os preceitos básicos da teologia neo-ortodoxa. Houve uma oposição ao pensamento liberal e fundamentalista, como afirma Roger Olson, em seu livro História da teologia cristã: 2000 anos de tradição e reformas, dizendo que os teólogos neo-ortodoxos procuravam uma forma moderna de teologia protestante, condizente com o Novo Testamento e com as principais ideologias de reformadores como Lutero, Zuínglio e Calvino. Olson declara que todos os pensadores ortodoxos, exceto Niebuhr, são cristocêntricos. ${ }^{3}$

Bengt Hägglund, em seu livro História da teologia, diz que eles também rejeitaram a teologia natural, apegando-se à Palavra de Deus como fonte e norma para a teologia cristã; também enfatizaram a diferença qualitativa infinita entre o tempo e a eternidade (herança kierkegaardiana). Foi uma volta à ortodoxia protestante, no que diz respeito à transcendência de Deus, que ele dizia ser o totalmente Outro, e uma oposição à imanência de Deus da teologia liberal. ${ }^{4}$ Contudo, não era totalmente ortodoxa no sentido histórico do termo, pois Barth rejeita o auxílio da filosofia no fazer teológico.

Em última instância, parafraseando Bengt Hägglund, a neo-ortodoxia foi um dos resultados da crise cultural que surgiram no fim da Primeira Guerra Mundial, criticando a teologia da escola da história das religiões; e também um protesto contra aquelas escolas que tinham transformado a teologia em ciência da religião e que tinham apresentado a análise do método histórico-crítico da Bíblia como a única interpretação possível. Barth não rejeitou este método de interpretação da Bíblia em si, mas acreditou que deixava

3 Cf. OLSON, Roger. História da Teologia Cristã: 2000 anos de tradição e reformas. Tradução de Gordon Chown. São Paulo: Editora Vida, 2001. p. 603.

4 Cf. HÄGGLUND, Bengt. História da Teologia. Tradução de L. Rehfeldt e Gládis Knak Rehfeldt. 7. ed. Porto Alegre: Concórdia, 2003. pp. 343-344. 
de atingir seu alvo porque se ocupava com questões periféricas e deixava de enfrentar os problemas reais nos textos estudados.

\section{A PALAVRA DE DEUS PARA KARL BARTH}

Barth pretendeu redescobrir o Evangelho sem o auxílio de um sistema filosófico. Assim, teve início a teologia da Palavra de Deus, outra designação para a teologia dialética ou da crise. Seu postulado teológico é que "a possibilidade do conhecimento de Deus encontra-se na Palavra de Deus e em nenhum outro lugar". Portanto, "O Deus eterno deve ser conhecido em Jesus Cristo e não em outro lugar". 5

A teologia dialética não rejeita, mas questiona o método histórico-crítico como chave de interpretação da Bíblia. A interpretação do método histórico-crítico se concentrava, em demasia, nas questões periféricas, ao passo que Barth enfatizava a proclamação como sendo o fundamental.

A autoridade da Palavra de Deus, segundo Barth, não pode ser submetida a critérios de pesquisa. A razão humana não pode ser o critério último para análise dos escritos bíblicos; a dimensão escatológica do ser divino deve ser preservada. "A única resposta que possui genuína transcendência, e assim pode resolver o enigma da imanência, é a Palavra de Deus - notem: a Palavra de Deus". 6

Com muita veemência, Barth rejeita qualquer modalidade de teologia natural. Para ele, Deus não pode ser conhecido pela capacidade da razão humana, nem se revela na natureza ou na história.

Essa recusa de Barth a qualquer tipo de teologia natural levou-o a travar uma disputa com o teólogo reformado Emil Brunner, que reconhecia a existência de um ponto de contato entre o Evangelho e a natureza humana. Brunner achava que a doutrina da eleição formulada por Barth desembocava no universalismo.

5 Cf. BARTH, Karl. Palavra de Deus, palavra do homem. São Paulo: Novo Século, 2004. p. 42.

6 Cf. BARTH, Karl. Palavra de Deus, palavra do homem. São Paulo: Novo Século, 2004. p. 153. 
Palavra de Deus, na neo-ortodoxia, segundo Karl Barth

Acentuando que a revelação de Deus aconteceu exclusivamente com Jesus Cristo, Barth posicionou-se contrário à doutrina católica romana da analogia entis (analogia do ser), contrapondo-se a analogia fidei (analogia da fé). Barth enfatiza que Deus é livre, soberano e transcendente; Ele se dirige ao ser humano por intermédio de sua Palavra, que também é livre e soberana.

A Palavra é o único fundamento de toda a teologia. Ela procede do próprio Deus, que permanece para sempre o seu sujeito. Por isso, ela tem autoridade, é infalível e insubstituível.

\section{CONSIDERAÇÕES FINAIS}

Barth, como grande teólogo do século $X X$, mostra a diferença e a responsabilidade do cristão que conhece a Palavra de Deus. A partir destes estudos é possível concluir que a Bíblia oferece um conhecimento de Deus e que o cristão deve confirmá-la em sua vida, além de anunciá-la aos que não a conhecem.

É por meio da Bíblia que se torna possível perceber a relação entre Deus e o ser humano. Deus é amor e, como na parábola do filho pródigo, Ele sempre vai atrás da ovelha perdida e, quando Ele encontra esta ovelha, a faz ser crente de forma que ela busque cada vez mais a percepção e a presença de Deus.

Deve-se compreender e meditar na Palavra de Deus porque a salvação vem Dele, e este conhecimento faz com que aumente o contato entre o humano e o Senhor. Uma compreensão amadurecida só é produzida mediante uma dependência do Espírito Santo, pois Ele conduz a Cristo, e essa união e compreensão trazem a transformação verdadeira e a vitória sobre o mal.

\section{REFERÊNCIAS BIBLIOGRÁFICAS}

BARTH, K. Introdução à Teologia Evangélica. Tradução de Lindolfo Weingartner.

São Leopoldo: Sindoval, 1981.

BARTH, K. Palavra de Deus, palavra do homem. São Paulo: Novo Século, 2004. GIBELLINI, R. A Teologia do Século XX. São Paulo: Edições Loyola, 1998.

GRENZ, S. J.; GURETZKI, D.; NORDLING, C. F. Dicionário de Teologia. São 
Paulo: Editora Vida, 2000.

HÄGGLUND, B. História da Teologia. Tradução de L. Rehfeldt e Gládis Knak Rehfeldt. 7. ed. Porto Alegre: Concórdia, 2003.

LACOSTE, J. Y. Dicionário crítico de teologia. São Paulo: Paulinas/Loyola, 2004.

LANDERS, J. Teologia Contemporânea. Rio de Janeiro: JUERP, 1986.

MACHEM, J. G. Cristianismo e liberalismo. Disponível em: <http:// solascriptura-tt. org/>. Acesso em: 10/05/2008.

MONDIN, B. Os grandes teólogos do século vinte: os teólogos protestantes e ortodoxos. Tradução de José Fernandes. V. 2. São Paulo: Paulinas, 1980.

OLSON, R. História da Teologia Cristã: 2000 anos de tradição e reformas. Tradução de Gordon Chown. São Paulo: Editora Vida, 2001.

PEREIRA, I. Dicionário grego-português e português-grego. Braga: Livraria Apostolado da Imprensa, 1990.

PIKAZA, X.; SILANES, N. Dicionário teológico: o Deus cristão. São Paulo: Paulus, 1988.

SOTELO, D.; COSTA, D.; Karl Barth A proclamação do Evangelho. São Paulo: Novo Século, 2000. 